not be included. But such questions can only be answered by intimate local knowledge.

The proposal itself and the principles on which it is based are sound; this bold and almost unique attempt to solve the language problem of such a vast region deserves every encouragement.

But M. de Jonghe goes even farther, and is of opinion that it would be better to push forward to the predominance of one of the four languages and to adopt it as the official native language of the whole Colony; and after an examination of the merits of the four he comes to the conclusion that in the competition, Luba seems to have most chances of success. Here we do not follow the author. The establishment of four (or five) common languages would mean a great success, it would meet the existing need and would in every way be more natural and more in agreement with actual conditions than the introduction of one language only.

\title{
Note on an Investigation of the Batciga.
}

The writer has recently returned from a year's stay among the Batciga, in the Kigezi district of Uganda. This is a tribe which has been overlooked completely in ethnological literature. They live in the western part of the lake region of East Africa, between Ruanda and Ankole. But their culture offers as sharp a contrast to that of their neighbours as does this bare, steep, mountain country to the rolling grass plains adjacent to them.

Among the Batciga there is no ruling, racially distinct, upper class. We find among them many basic similarities and even identities with the better known cultures which have such a class, but in every field we find aspects which are fundamentally different. It is hoped that this investigation of what is perhaps a unique situation may help to shed light on the complicated problems of culture history in this region and the more general theoretical ones of cultural change.

To the Mutciga peasant, a cow is but live stock, greater in value than his flocks, and therefore more significant economically; but surrounded with none of the familiar ceremonies and taboos. He is an extreme individualist. The clans are autonomous and even within them there is no strongly centralized authority. In religion we may note typical patterns-ancestor-worship, a cult of less personal spirits, a paraphernalia of diviners and shamans. But all are very much less richly developed, and lack legendary amplification. There is also a spirit which is superior in power to the others and has a priesthood. This is informal and unorganized, but has certain semi-political prerogatives, which seem to be modelled after those of the Watussi chiefs of Ruanda. The situation is similar in the realm of material culture. The Batciga practise most of the techniques of their neighbours, but have absolutely no art, decorative or abstract. 
To-day the situation in the British portion of this tribe's territory is rather a curious one. Economically and politically they are making a satisfactory adjustment, the changes being rather more complete in the latter, and only very slight in the former, field. Socially their own essential patterns have not suffered much interference. It is in the field of religion that the greatest disturbances have occurred. The government has seen fit to place a sweeping ban on all expressions of the old complex. It has been sufficiently powerful to enforce this, so that for the most part all the practices are in abeyance, and the younger generation is growing up with no obstacle in the path of its Christianization, which is progressing rapidly from a very recent start. Fortunately it was possible to obtain not only a picture of life to-day but also reliable information on customs and conditions as they were one generation ago-which means for the Batciga prehistorically.

The work was done under the auspices of the National Research Council in the United States.

(Communicated by MAY MANDELbaum EDEL.)

\section{'Togo-Cameroun', Magazine trimestriel publié par l'Agence Economique des Territoires Africains sous Mandat.}

Il convient de signalet une fois de plus aux lecteurs d'Africa cette publication susceptible de les intéresser à plus d'un titre. En dehors d'une documentation économique et administrative qui a son importance, on trouve dans le numéro d'avril 1934 une série d'études sur les populations du Cameroun septentrional. La plupart sont dues à la plume de M. Émile Buisson qui a exercé des fonctions administratives dans cette région. Sa formation scientifique lui a permis de recueillir des informations particulièrement intéressantes sur le milieu et ses habitants. Il les expose dans une série de notes : Généralités sur les groupements kirdi du nord de Garoua; Le plateau oriental de Guidder, pays kirdi; les cultures kirdi-guidder et les cérémonies agraires; funérailles d'un chef de village kirdi; cérémonies funéraires chez les Kirdi-Falli; le sel chez les Kirdi; préhistoire kirdi; légendes de Bidzar, du Tinguélin. Ces diverses études sont appuyées par cinq cartes extrêmement claires donnant l'emplacement des différents groupements étudiés. De plus, de très nombreuses photographies bien venues et bien choisies précisent l'aspect géographique et les particularités ethnographiques, en particulier celles relatives à l'habitation, au vêtement, à l'armement et aux funérailles.

L'auteur a pu comparer un grand nombre de faits observés chez les Moundang et chez les Kirdi, il a constaté que la structure des habitations est la même dans les deux peuplades et que plusieurs coutumes agraires coïncident absolument. Il en conclut que ces deux tribus sont ou de même origine, ou bien qu'elles se sont empruntées des techniques, des rites et des institutions.

On remarquera que $\mathbf{M}$. Buisson emploie pour désigner les populations qu'il étudie le terme de kirdi qui est manifestement la déformation de kerada, 